\title{
特集 水産微生物のリアルタイムモニタリング
}

\section{海洋での流出油事故と微生物のモニタリングーメソコスム実験}

\author{
大和田紘一, $1 *$ 西 村 昌 彦 2 \\ 1熊本県立大学環境共生学部, 2東京大学海洋研究所
}

\begin{abstract}
Microbial monitoring during oil spill accidents in marine environment-mesocosm experiments
\end{abstract}
\section{KOUICHI OHWADA ${ }^{*}$ AND MASAHIKO NISHIMURA ${ }^{2}$}

${ }^{1}$ Faculty of Environmental and Symbiotic Sciences, Prefectural University of Kumamoto, Kumamoto, Kumamoto 862-8502, ${ }^{2}$ Ocean research institute, University of Tokyo, Nakano, Tokyo 164-0014, Japan

\section{1. はじめに}

原油あるいは重油の流出事故はこれまでも世界中の沿 岸域で起こり，大きな災害となってきた。この中で特に 大きいのは湾岸戦争やメキシコ湾油田事故による油田か らの流出油である。その他はナホトカ号などタンカー事 故による流出がかなり多く, 国際油濁統計によると 1967 年以降の 30 年間では大きなタンカー事故が平均で 3 年に 2 回の割合で起こっているという。我が国でも, 三菱・水島精油所 (1974 年), ジュリアナ号 (1971 年), ナホトカ号（1997 年）なぞ大きな流出油の事故が上げ られる。1 海洋に流出した石油成分は, 揮発して大気に 放出されたり，微生物による分解を受けて浄化された り，また分解を受けにくい成分は固形となって漂着ある いは海底に沈んでいくなどさまざまな運命をたどりなが ら，海域は浄化されていく。2)

著者らはナホトカ号の事故の後, 日本学術振興会の未 来開拓推進事業の中で, 流出油の沿岸生態系への影響評 価に関する研究を行う機会があったので，その結果の一 部について紹介をしたい。浜名湖に面した静岡県浜名郡 舞阪町にある東京大学大学院農学生命科学研究科付属水 産実験所構内の魚類飼育用コンクリート水槽内にメソコ スム装置を建造した。メソコスムは直径 $1.5 \mathrm{~m}$ ，高さ $3.0 \mathrm{~m}$ の強化プラスチック製円形水槽（容量 5,000 リッ トル） 4 基と同じ大きさの貯水槽 2 基から構成され， 20 $\mathrm{rpm}$ で回転する攪拌装置と底には堆積物を $10 \mathrm{~cm}$ の厚 さに敷くことの出来るトレイ，また透明なプラスチック による上面のカバーを備えている。実験用の海水はすぐ 隣の浜名湖の表面水を水中ポンプによって採取し，地中 の配管を通じて直接に貯水槽に送って貯留し，そこから ポンプによって実験水槽に供給するようにした。メソコ スムの詳しいことに関しては Ohwada et al.3)あるいは

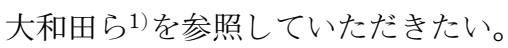

\section{2. メソコスム実験}

石油のモデル試料として昭和シェル石油製の $\mathrm{A}$ 重油 を用い，海水 10 リットルに A 重油 $500 \mathrm{~g}$ の割合で混ぜ, $800 \mathrm{rpm}$ で 2 時間攪拌した後の水画分を水溶性画分とし てメソコスムに負荷して実験を行った。メソコスムタン クには浜名湖の表面水をポンプで汲み上げ，そこに 30 リットルの水溶性画分を負荷して実験を行った。また, 分散型石油処理剤（分散剂）を使っての実験では, 水溶 性画分 30 リットルに分散剂（タイホー工業, Taiho self mixing S-7) $120 \mathrm{~g}$ を加え, 対照区として海水のみ のタンクと比較した。これらのタンクは, 備え付けの覺 拌装置を用いて 30 分間攪拌後，実験を開始した。

重油成分の分析は GC-MS 法, ${ }^{4)}$ 細菌の計数は DAPI を用いる蛍光顕微鏡法, 5) ウイルスの計数はSYBR Green I を用いる蛍光顕微鏡法, ${ }^{6)}$ 細菌増殖速度の指標 としての FDC（分裂細胞の割合）は Hagstrom et al. ${ }^{7}$ に従った。海水中の細菌の濃縮とDNA 抽出精製は Somerville et al. ${ }^{8)}$ Steward et al. $\left.{ }^{9}\right)^{\prime}$ に準拠し, Muyzer et al. ${ }^{10)}$ の方法でゲル上に展開されたバンドパターンを解 析した。

（1）重油成分分解過程での微生物群集の遷移 ${ }^{11)}$

重油負荷区（oil）々対照区（con）での重油成分 (PAHs), 細菌の増殖速度 (FDC), 細菌数抒よびウイ ルス数の経時変化を図 1 に示した。重油負荷区におい ては，重油成分を添加後急速に細菌の増殖速度が上がる と同時に細菌数も急激に高くなっている。一方，重油の 低分子量成分の naphthalene や phenanthrene は急激に 減少した。また細菌数の増加に伴って, ウイル数も急激 に増加しているのも興味がある。重油低分子成分の分解 に係わる細菌の増加に伴って，その細菌に感染するウイ ルスが増加したものと考えられる。一方，対照区におい てはこの間にほとんど変化が認められない。図 $2 に$ は, メソコスム海水中の細菌から増幅した $16 \mathrm{~S}$ rDNA

* Tel. : 81-96-383-2929. Fax : 81-96-384-6765. Email : ohwada@pu-kumamoto.ac.jp 

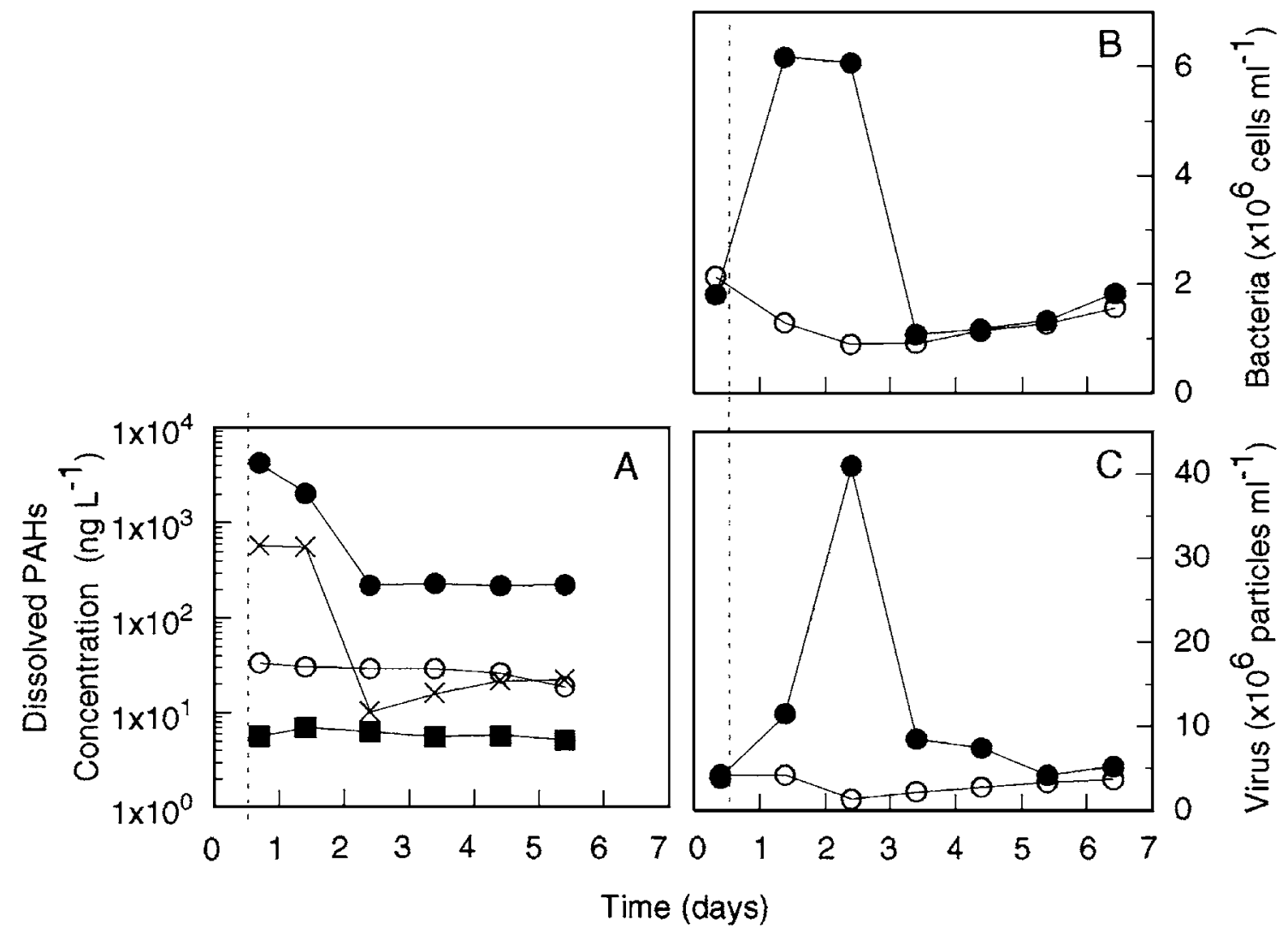

図 1 重油成分負荷タンクと対照タンクに抢ける重油成分と微生物数の変化

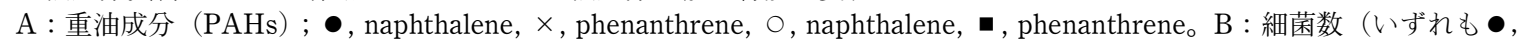
負荷タンク, $\mathrm{O}$, 対照タンク)。C : ウイルス数 $(\bullet$, 負荷タンク, $\mathrm{O}$, 対照タンク)。

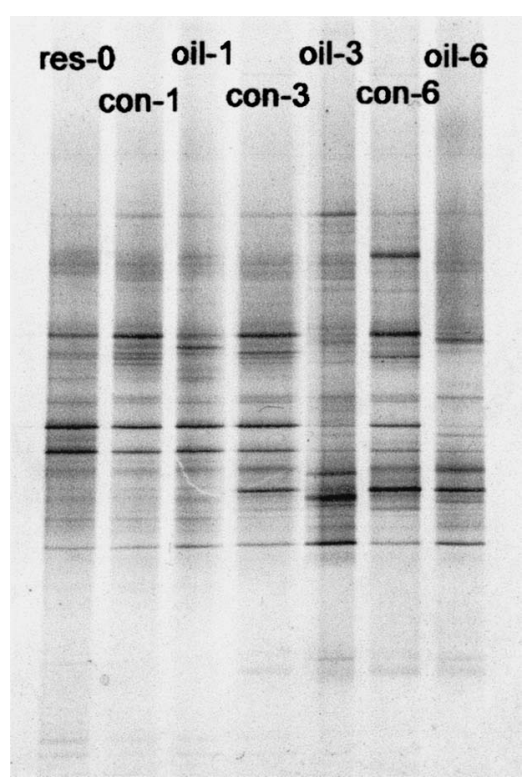

図 2 16S rDNA 断片の DGGE 法によるバンドパターン res-0 : 実験開始時のタンク。oil-1, oil-3, oil-6 : 負荷 タンクのそれぞれ 1 日, 3 日, 6 日後。con-1, con-3, con-6 : 対照タンクのそれぞれ 1 日，3 日，6日後。

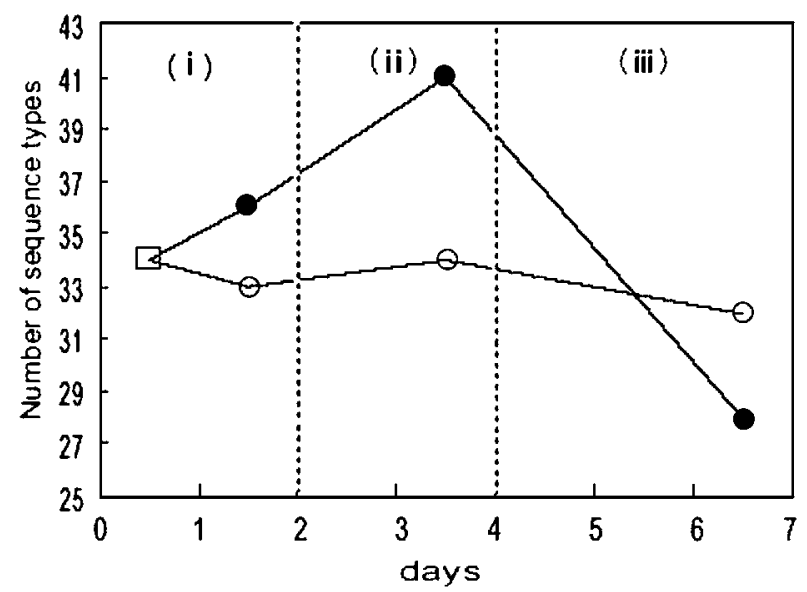

図 3 DGGE 法によるバンド数の時間経過 •, 負荷タンク, ○, 対照タンク。

遺伝子断片の DGGE バンドパターンを，また図 3 には この間のバンド数の変化を示した。重油成分の負荷前と 初めの 24 時間くらいは, バンドパターンに変化がなく 約 34 本のバンドであるが， 3 日後には重油添加区では 41 本に変化し， 6 日後には急激に減少して 27 本になっ 


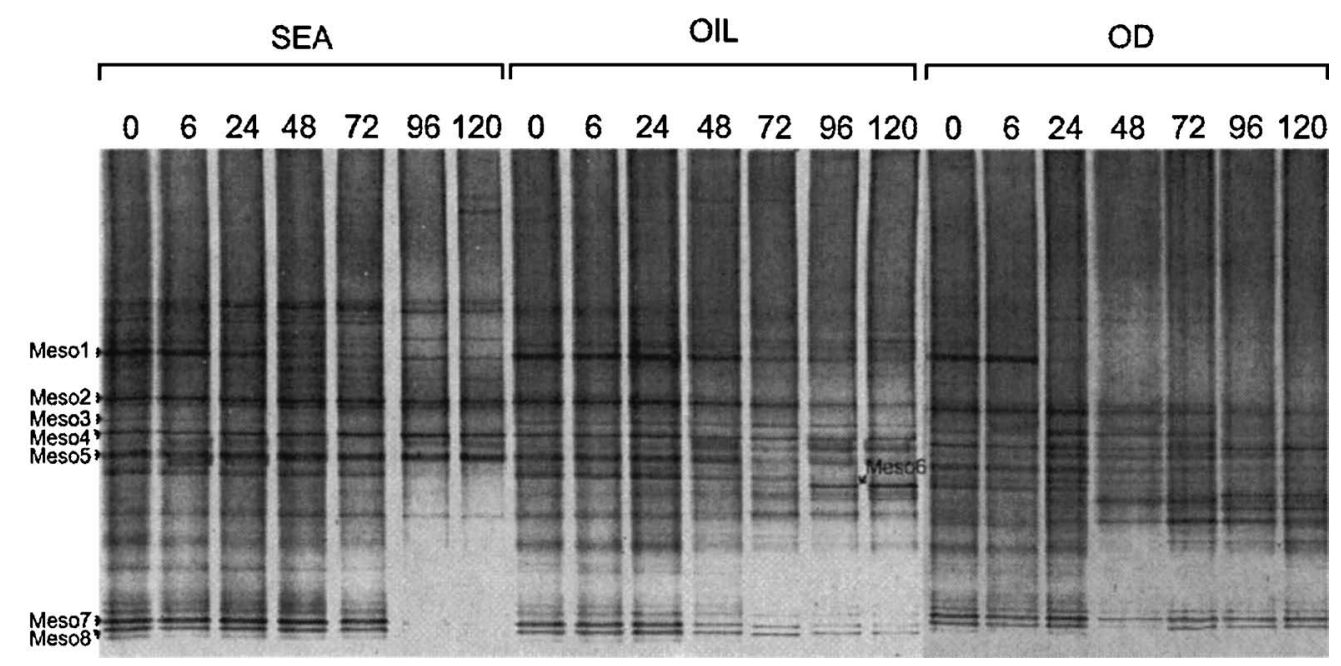

図 4 16S rDNA 断片の DGGE 法によるバンドパターン

SEA : 対照タンク, OIL : 重油添加タンク, OD : 重油十分散剤添加タンク。

ていた。一方，対照区ではバンド数にはほとんど変化が 認められなかった。これらは重油成分の内の低分子成分 が実験開始後, 3 日くらいで海洋細菌によって急激に分 解を受けていることを示しており，急激に増加した，い くつかのバンドに相当する細菌群集がこの分解に関与し ていることを示している。

（2）重油成分および分散剂を加えた系での微生物群集 の遷移4)

対照タンク (SEA), 重油添加タンク (OIL), 重油+ 分散剤タンク $(\mathrm{OD})$ を用いての 120 時間の実験の例で は, 細菌数は SEA タンクで, $1.0-2.0 \times 10^{6} \mathrm{cells} / \mathrm{mL}$ と 大きな変動はなく, また OIL タンクにおいては，1.8$3.7 \times 10^{6} \mathrm{cells} / \mathrm{mL}$ と変動したが, 重油添加後 24 時間に ピークに達し，その後は減少していった。それに対して， OD タンクにおいては, 開始時には $2.3 \times 10^{6} \mathrm{cells} / \mathrm{mL}$ だったのが，急激に増加をして 72 時間後には $6.0 \times 10^{6}$ cells $/ \mathrm{mL}$ に達していた。この過程の DGGEパターンを 図 4 に示した。SEA 抢よび OIL タンクにおいては実験 期間中，バンドパターンが比較的安定しているのに対し て, OD タンクに打いては 24 時間後からパターンに変 化が認められている。さらに解析を進めるために多次元 尺度法によるクラスター解析を行った結果を図 5 に示 した。この図からは, 細菌群集は 3 つのグループに明 瞭に分かれ, SEA とOIL タンクではグループIから IIa に遷移しているのに対して, OD タンクの細菌群集 はグループIから全く異なるグループIIbに遷移したこ とが分かる。主なバンドを構成する細菌については系統 解析によって，その分類学的な位置も明らかにされてい る。この実験の例においては初めの 24 時間くらいの間 に低分子の重油成分の分解に関与しているが，それ以降 に颃いては分散剤に反応していることが分かる。これに

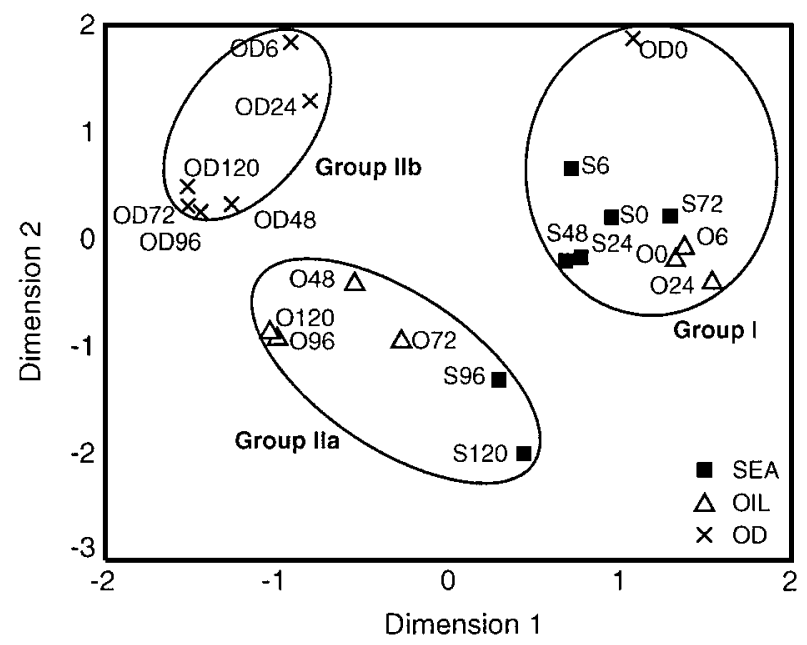

図 5 バンドパターンに基づく多次元尺度法によるクラ スター解析

- : 対照タンク, $\triangle$ : 重油添加タンク $\times$ : 重油 + 分散剂添加タンク, 数字は経過時間を示す。

ついてはさらに検討を行い, 細菌群集はこの分散剂を分 解していることを確かめている。

3. おわりに

私どもは重油の水溶性画分に焦点を絞り, メソコスム の中に浜名湖の表面海水を導入して, 実験を行った。本 稿ではその中の細菌群集の変化をモニターすることに限 定して紹介した。非常に濃度が希薄であっても, 海水中 に重油の水溶性画分が入ってくると, まず細菌群集が活 発に低分子画分の分解に当たり, 増殖していく。ある種 の細菌群が活発な増殖を始めると, その捕食者としての 従属栄養性鞭毛虫や繊毛虫などの原生動物の増殖が始ま る。これと同時に細菌に感染するウイルス (バクテリオ ファージ）なども活動を始めることが明らかになった。 
これは即ちマイクロビアルループに関係した微生物群集 が活性化されたことを意味している。また微生物による 分解を受けにくい高分子の成分は植物プランクトンや懸 濁粒子に吸着して，海底へと輸送されることも明らかに なった。 ${ }^{3)}$ ナホトカ号の事故の際には，この事故に近い 海域において細菌群集の中では Cycloclasticus pugetii が 急激に優占種となり, 油の分解に関与していた過程が報 告されている。12)

\section{謝辞}

本研究を行うに当たり, 東京大学大学院農学生命科学 研究科付属水産実験所の教官と職員の方々に大変扔世話 になったことに謝意を表したい。本研究は日本学術振興 会の未来開拓推進事業の一環として行われた。

\section{文献}

1) 大和田紘一, 西村昌彦, 和田 実, 野村英明, 柴田 晃, 岡本 研, 豊田圭太, 吉田明弘, 高田秀重, 山田美 穂子. 重油の微量水溶性画分が沿岸生態系に与える影響 に関するメソコスム実験. 海洋微生物-II基礎, 応用研究 とその利用. 月刊海洋号外 2003; 35: 113-119.

2) 大和田紘一. 石油の分解除去.「海の環境微生学」（石田 祐三郎, 杉田治男編）恒星社厚生閣，東京. 2005; 204209.

3) Ohwada K, Nishimura M, Wada M, Nomura H, Shibata H, Toyoda K, Yoshida A, Takada H, Yamada M. Study of the effect of water-soluble fractions of heavy oil on coastal marine organisms using enclosed ecosystems, mesocosms. Mar. Poll. Bull. 2003; 47: 78-84.

4) Yoshida A, Nomura H, Toyoda K, Nishino T, Seo $Y$, Yamada M, Nishimura M, Wada M, Okamoto K, Shibata
A, Takada H, Kogure K, Ohwada K. Microbial responses using denaturing gradient gel electrophoresis to oil and chemical dispersant in enclosed ecosystems. Mar. Poll. Bull. 2006; 52: 89-95.

5) Porter KG., Feig YS. The use of DAPI for identifying and counting aquatic microflora. Limnol. Oceanogr. 1980; 25: 943-948.

6) Noble RT, Fuhrman JA. Use of SYBR Green for rapid epifluorescence count of marine viruses and bacteria. $A$ quat. Microb. Ecol. 1998; 14: 113-118.

7) Hagstrom A, Larsson U, Horstedt P, Normark S. Frequency of dividing cells, a new approarch to the determination of bacterial growth rates in aquatic environments. Appl. Environ. Microbiol. 1979; 37: 805-812.

8) Somerville CC, Knight IT, Straube WL, Colwell RR. Simple, rapid method for direct isolation of nucleic acids from aquatic environments. Appl. Environ. Microbiol. 1989; 55: 548-554.

9) Steward GF, Azam F. Bromodeoxyuridine as an alternative to $3 \mathrm{H}$-thymidine for measuring bacterial productivity in aquatic samples. Aquat. Microb. Ecol. 1999; 19: 57-66.

10) Muyzer G, Dewaal EC, Uitterlinden AG. Profiling of complex microbial populations by denaturing gradient gel electrophoresis analysis of polymerase chain reaction-amplified genes coding for $16 \mathrm{~S}$ rDNA fragments. Arch. Microbiol. 1995; 164: 165-172.

11) Nishimura M, Yoshida A, Toyoda K, Yamada M, Nomura H, Wada M, Okamoto K, Shibata A, Takada H, Ohwada $\mathrm{K}$. Mesocosm experiment on the succession of microbial community in response to oil contamination to coastal seawater. La mer 2006; 44: 59-65.

12) Maruyama A, Ishiwata $H$, Kitamura $H$, Sunamura $M$, Fujita T, Matsuo M, Higashihara T. Dynamics of microbial populations and strong selection for Cycloclasticus pugetii following the Nakhodka oil spill. Microb. Ecol. 2003; 46: 442-453. 